\title{
Ethnopharmacological study of medicinal plants used in Rosário da Limeira, Minas Gerais, Brazil
}

\author{
Helaine B. de Oliveira, * Carolina W. Kffuri, Vicente W. D. Casali \\ Departamento de Fitotecnia, Universidade Federal de Viçosa, Avenida Peter Henry Rolfs s/n, \\ Campus Universitário, 36570-000 Viçosa-MG, Brazil.
}

\begin{abstract}
RESUMO: "Estudo Etnofarmacológico de Plantas Medicinais utilizadas em Rosário da Limeira, Minas Gerais, Brasil". Em virtude da importância do saber popular na utilização de plantas medicinais e da contribuição desse saber na preservação da flora medicinal, o trabalho atual tem o objetivo de resgatar e sistematizar o conhecimento popular de espécies medicinais e sua relação com usos terapêuticos, em Rosário de Limeira, MG. Os dados foram coletados entre janeiro e março de 2007. Quinze informantes foram entrevistados sobre seus conhecimentos das espécies medicinais, residentes nas comunidades rurais e nos bairros do município. A pesquisa revelou o uso de 66 espécies pertencentes a 33 famílias (Asteraceae com o maior número de espécies, seguido por Lamiaceae, Rutaceae e Bignoniaceae) usadas no tratamento de várias patologias. Das espécies medicinais citadas, $44,3 \%$ crescem espontaneamente e $55,7 \%$ são cultivadas. A principal parte vegetal usada na preparação dos fitoterápicos é a folha e a preparação mais comum é a infusão. As espécies mais usadas são: Baccharis trimera, Mentha sp., Plantago major, Chenopodium ambrosioides e Symphytum officinale.
\end{abstract}

Unitermos: Etnobotânica, plantas medicinais, conhecimento tradicional, etnofarmacologia.

\begin{abstract}
In order to evaluate the popular knowledge on the use of medicinal plants and the contribution in the preservation of medicinal flora, the present work aims to rescue and organize such knowledge on medicinal species and its relation with therapeutic uses, in the city of Rosario de Limeira, MG. Data were collected January to March, 2007. Fifteen informants, all resident in urban and agricultural communities, were asked about their knowledge on medicinal plants. The current survey revealed the use of 66 species belonging to 33 families (Asteraceae with the major number of species, followed by Lamiaceae, Rutaceae, and Bignoniaceae) used in the treatment of various diseases. $44,3 \%$ of them grow spontaneously and 55,7\% are cultivated. The main vegetal part used in the preparation of the phytotherapy was the leaf, and the most common preparation was the infusion. The most used species were: Baccharis trimera, Mentha sp., Plantago major, Chenopodium ambrosioides and Symphytum officinale.
\end{abstract}

Keywords: Ethnobotanic, medicinal plants, traditional knowledge, ethnopharmacology.

\section{INTRODUCTION}

Medicinal plant is any vegetal that containing substances, that can be used therapeutically. These plants are widely used by the alternative medicine (Amorozo, 2002). The factor that favors the area of natural products in Brazil is the ethnobotanic and ethnopharmacological knowledge of the Brazilian population. Peoples of African origins and Europeans brought to Brazil their knowledge on the use of medical plants, joining with the experience of the native populations. The spread of this knowledge facilitated the popular acceptance of phytoterapics.

Ethnobotanic includes all the pertinent studies on the mutual relation between traditional populations and the plants (Cotton, 1996). The basic characteristic of the ethnobotanic study is the direct contact with traditional populations, rescuing all possible knowledge on the relation of affinity between inhabitants and plants. Many ethnobotanic studies are being developed both in Brazil and in the world, searching for a better knowledge of the medicine of traditional peoples and/or contemporaries, and for a better scientific organization of this popular knowledge. These studies look for plants with therapeutical activity, allowing the discovery of new active principles. Many modern drugs have origin in traditional medicine, ethnobotanic and ethnopharmacology (Patwardhan, 2005). Ethnopharmacology and drug discovery using natural products remain important issues in the current target-rich, lead-poor scenario (Patwardhan et al., 2004). Ethnobotanic researches promote culture rescue, traditional knowledge register and information collection on the empirical uses of plants which are in process of disappearance (Martinez, 
1997). Beyond the cultural rescue, this type of survey has as benefits, that the results of the researches are returned to the people who helped, helping the preservation of these traditions generation after generation, with the add of scientific strenght to traditional cultures (Rasp, 2000). Aiming to contribute to the preservation of popular knowledges on native plants useful for the human health, this research intends to systemize the knowledge regarding medicinal plants of the inhabitants of the urban and agricultural area of Rosário da Limeira MG, as well as recording informations related to preparation, indications of use and used parts of the exploited species.

\section{MATERIAL AND METHODS}

The study area, Rosário da Limeira-MG (20 $58^{\prime} 44$ $43^{\prime \prime} \mathrm{S}$ and $42^{\circ} 30^{\prime} 43^{\prime \prime} \mathrm{W}$ ), lies in the Brigadeiro mountain range. The climate is considered tropical of altitude; the predominant relief is the mountainous $(55 \%)$, followed of the waved (30\%) and plan (15\%). The city of Rosário da Limeira locates in the "Zona da Mata" of the State of Minas Gerais, at the altitude of $650 \mathrm{~m}$, with minimum of $600 \mathrm{~m}$ and maximum of $1800 \mathrm{~m}$ (Rosário da Limeira, 2007). The field data have been collected from January to March, 2007 in the urban part and agricultural communities. We interviewed fifteen informants of both sexes, age varying from 27 to 73 years old, chosen for previous survey. In the interviews, structurized forms was used (Martin, 1995), asking questions referring to the interviewed (local residence, name, age, sex, instruction degree, years of residence in the place, region of origin and with whom the use of medicinal plants was learned), to the plants (popular name, used parts, therapeutic indication, form of use and way of preparation), to the main illnesses and/or symptoms. Each interview was registered by recorder preventing loss of information.

Described plants were photographed and their identification was confirmed by comparison to the specimen stored in the herbarium of the Federal University of Viçosa (MG, Brazil).

During the organization of recorded data, we transcripted the content of recordings as recommended by Bardin (1988), or we grouped the various informations in analytical categories, to better study the frequency of similar answers on our questions. Some answers we obtained were impossible to classify in the purposed categories, but yet we couldn't discharge them, because, despite unusual, they had great relevance to the issues of our research.

According to the methodology proposed by Amorozo \& Gély (1988), we calculated the Index of Relative Importance (IR) of medicinal plants used in communities and at the headquarters of the council, the number of informants who cited the agreement and the usage. We excluded from this calculation only the species mentioned by just one informant. The Index of Relative
Importance is obtained by calculating the percentage of agreement on the main uses of each species (CUP). Considering that the main uses meet the most cited indications, CUP is calculated as follows:

\section{$C U P=$ Number of informants citing main uses $\mathrm{x} 100$ Number of informants citing use of the species}

Later the value of CUP was corrected by the correction factor of $\mathrm{FC}$ where:

$$
F C=\text { Number of informants citing the species } \times 100
$$

The CUP is given then corrected by the formula CUPc $=$ CUP $x$ FC which is equivalent to IR.

\section{RESULTS AND DISCUSSION}

Among the fifteen informants of Rosário da Limeira, thirteen of them were proceeding from agricultural communities, two from the urban part. Interviewed indicated different species of plants, taxonomically identified as 66 different species, distributed in 33 families, being the Asteraceae with bigger number of species $(30,0 \%)$, followed by Lamiaceae $(26.0 \%)$, Rutaceae e Bignoneaceae with $8,0 \%$ each (Table 1). The more cited plant was the "transagem" (Plantago major L.).

The vegetal species cited on survey are listed in Table 1, including family, regional vulgar name, used part and therapeutical indication. All the interviewed (average 40 years old) had demonstrated knowledge about medicinal plants. In the work of Rodrigues et al. (2002), in Luminárias, interviewed ages varied from 32 to 89 years old. The use of the medicinal plants in the region is passed generation to generation. According to Amorozo (1996), the main way of knowledge transmission in traditional societies is verbal, and the transmission between generations requires intense contact between younger and older members of the society. Although, the cultural inheritance has been the biggest source of learning regarding plants with medicinal use, and in this survey we found a great interest from interviewed in acquiring more information about medicinal plants, so they look for external sources as books, magazines and courses promoted by universitarian institutions, indicating strong influence of these sources in their knowledge. Research institutions can contribute to the dissemination of information, spreading in accessible form the results obtained in complementary studies in this area.

Four of the interviewees were men and eleven were women. According to Rodrigues \& Casali (2002), women hold more knowledge on medicinal plants and have important function in the transmission process. Dias (1999) related the differentiations of the knowledge holding 
by women and men in daily activities, the women, in this study, were responsible for the culture and the preparation of the medicinal plants, as well as for the food preparation and care of the family, children and others. According to Amorozo \& Gély (1988), there are differences between the knowledge of the man and the woman. In general women dominate the knowledge of the plants that grow near to residence, while men know more the plants that grow on the fields. This specialization is not rigid, some women know the remedies of the fields as well as their husbands. Women and men have traditionally had separate duties, and each gender moves through these spaces differently (Müller-Schwarze, 2006).

Asked about the risk of the use of the phytotherapy, 93,3\% had answered that plants, when badly indicate or prepared, may cause some type of toxic effect demonstrating the awareness with the correct use of medicinal plants. The vegetal part more used in the preparation of the remedies is the leaf $67.69 \%$ followed by flower $9.23 \%$ and rind $6.15 \%$ (Table 1). Analogous results can be observed in the work carried through for Rasp (2000). The most common way of preparation is infusion $(60.3 \%)$, followed by the decoction (20.66\%) (Table 1$)$. In accordance with Castellani (1999), the infusion is used to prepare all tender parts of medicinal plants such as leaves, buttons and flowers, rich in volatile components, delicate aromas and active principles, degraded by the action of water and heat. It has been observed, the most common use of medicinal plants is in cases of illnesses involving inflammations, infectious diseases and cold or fever (Table 1). It observed that the same plant is used to treat several pathologies, and frequently inhabitants prepare together two or more vegetal species, indicating the use of associations of plants.

Eleven interviewees were native from the city and had lived there for more than 10 year. The majority of the medicinal plants they use are cultivated in small gardens or balconies, but native plants are collected in the field. In this study, many plants are used traditionally by the inhabitants, this information is transmitted from generation to generation orally, and through research and studies regarding the medicinal plants on youngest. Although the increase of the contact with medicines acquired in pharmacies, the communities of this area keep in practice the use of remedies from medicinal plants as viable remedy for some illnesses. Since the implantation of the Program of Phytotherapy on the Government System of Health (SUS) in Rosário da Limeira, it has been observed a rescue in the knowledge of medicinal plants, having, today, a concern to transmit this to youngest. The majority of the people have conscience of the plants as medicinal for primary medical assistance. Moreover, it has been seen, the interviewees take the necessary cares to the use of the plants: they know how to collect in appropriate places and they can identify correctly the medicinal species. It has also observed, the cultivated plants are those of traditional use in the popular medicine and the acquired native plants directly of the field. This preliminary result shows, the extraction of native plants is a common habit and the population must be reported about the actual damages to the species with predatory extraction.

The Index of Relative Importance (RI) was calculated in relation to 36 species $(60 \%$ of the total of identified medicinal plants) because only 24 species have been cited by an informant. This index was obtained by calculating the CUPc (corrected percentage of agreement on the main uses). According to Amorozo \& Gély (1988) the values of RI are in the range of 0 to 100 . The authors explain, values of IR between 0 and 24 indicate species little used by the community, between 25 and 49 , intermediate use species and between 50 to 100 , widely used species by the community.

In most medicinal species (61.2\%) cited by informants, the value of the RI index was between 25 and 49 (species of intermediate use). RI was low in about $13.8 \%$ of the species (little use) and the RI of $25.0 \%$ of the species was high, indicating plants that are widely used by the population of the municipality.

Table 1. Vegetal species used as medicinal plants among the inhabitants of the city of Rosário da Limeira. Common and scientific names, family, application, plant part, method, environment and Relative Importance R.I.)

\begin{tabular}{llcccc}
\hline Species & \multicolumn{1}{c}{ Application } & Plant part & Method & Environment & R.I. \\
\hline Abacate (Persea americana, Lauraceae) & throat infection, bladder & Leaf & Infusion & Cultivated & N.C. \\
& infection, cough & & & & \\
Açoita-cavalo (Luthea divaricata, Tiliaceae) & pain & Bark & Decoction & Cultivated & 25.0 \\
Agrião (Nasturtium officinalis (Brassicaceae) & anemia, liver problems & Leaf & Infusion & Cultivated & 25.0 \\
Alecrim (Rosmarinus officinalis, Lamiaceae) & anxiety & Leaf & Infusion & Cultivated & 37.5 \\
Alfavaca (Ocimum sp., Lamiaceae) & constipation & Leaf & Decoction & Cultivated & 12.5 \\
Algodão (Gossipium sp., Malvaceae) & infection & Leaf & Infusion & Cultivated & 50.0 \\
Ameixa (Prunus domestica, Rosaceae) & intestine regulation & Fruit & Maceration & Cultivated & N.C. \\
Amora (Morus alba, Moraceae) & hormonal reposition & Leaf & Infusion & Cultivated & N.C. \\
Arnica (Solidago chilensis, Asteraceae) & pain and inflammation & Leaf & Maceration & Cultivated & 25.0 \\
Arruda (Ruta graveolens, Rutaceae) & inflammation & Leaf & Maceration & Cultivated & N.C. \\
\hline
\end{tabular}




\begin{tabular}{|c|c|c|c|c|c|}
\hline Babosa (Aloe ferox, Liliaceae) & skin, burn & Leaf & Maceration & Cultivated & 25.0 \\
\hline Bardana (Arctium lappa, Asteracea) & kidney problems & Leaf & Infusion & Cultivated & 50.0 \\
\hline Berinjela (Solanum melongena, Solanaceae) & lower cholesterol & Fruit & Decoction & Cultivated & N.C. \\
\hline Boldo (Vernonia condensate Asteraceae) & bad digestion, liver & Leaf & Maceration & Cultivated & 25.0 \\
\hline Calêndula (Calendula officinalis Asteraceae) & allergy & Flower & Decoction & Cultivated & 12.5 \\
\hline Camomila (Chamomilla recutita Asteraceae) & tranquilizer and digestive & Flower & Infusion & Cultivated & 37.5 \\
\hline Cana-de-macaco (Costus spicatus, Zingiberaceae) & diuretic and lower pression & Leaf & Infusion & Spontaneous & 25.0 \\
\hline Capeba (Piper sp., Piperaceae) & diuretic & Leaf & Infusion & Spontaneous & N.C. \\
\hline Capim-cidreira (Cymbopogon citrates, Poaceae) & analgesic, calmant, fever & Leaf & Infusion & Cultivated & 25.0 \\
\hline Caroba (Jacaranda caroba, Bignoniaceae) & anti-rheumatic & Leaf & Infusion & Spontaneous & N.C. \\
\hline Carqueja (Baccharis trimera, Asteraceae) & diabetes, vermifuge & Leaf & Infusion & Spontaneous & 50.0 \\
\hline Cavalinha (quisetum sp., Equisetaceae) & $\begin{array}{l}\text { arthritis, arthrosis and } \\
\text { blood depurative }\end{array}$ & Root & Decoction & Spontaneous & 37.5 \\
\hline $\begin{array}{l}\text { Chapéu-de-couro (Echinodorus macrophyllus, } \\
\text { Alismataceae) }\end{array}$ & blood depurative & Leaf & Infusion & Cultivated & 50.0 \\
\hline Coentro (Coriandrum sativum, Umbelliferae) & menstrual colic & Entire plant & Decoction & Cultivated & N.C. \\
\hline Confrei (Symphytum officinale, Boraginaceae) & healing and slimmer & Leaf & $\begin{array}{l}\text { Maceration } \\
\text { and infusion }\end{array}$ & Cultivated & 62.5 \\
\hline Dente-de-leão (Taraxacum officinale, Asteraceae) & $\begin{array}{l}\text { cholesterol and high } \\
\text { pressure }\end{array}$ & Leaf & Infusion & Cultivated & 25.0 \\
\hline Erva-cidreira (Lippia alba, Verbenaceae) & antiespasmodic & Seed & Decoction & Cultivated & 25.0 \\
\hline $\begin{array}{l}\text { Erva-de-são-joão, (Ageratum conyzoides, } \\
\text { Hypericaceae) }\end{array}$ & antidepressive & Leaf & Infusion & Spontaneous & N.C. \\
\hline $\begin{array}{l}\text { Erva-de-santa-maria, (Chenopodium ambrosioides, } \\
\text { Chenopodiaceae) }\end{array}$ & vermifuge & Leaf & Infusion & Spontaneous & 50.0 \\
\hline Espinheira-santa (Maytenus ilicifolia, Celastraceae) & stomach acidity & Leaf & Infusion & Cultivated & 12.5 \\
\hline Eucalipto (Eucaliptus globulus, Myrtaceae) & diabetes & Leaf & Infusion & Spontaneous & N.C. \\
\hline Funcho (Foeniculum vulgare, Umbeliferae) & flatulence, calmant & Leaf & Infusion & Cultivated & 37.5 \\
\hline Gengibre (Zingiber officinale, Zingiberaceae) & expectorant & Root & Decoction & Cultivated & N.C. \\
\hline $\begin{array}{l}\text { Gervão-azul (Stachytarpheta jamaicensis, } \\
\text { Verbenaceae) }\end{array}$ & diabetes & Leaf & Infusion & Spontaneous & 25.0 \\
\hline Guaco (Mikania glomerata, (Asteraceae) & cough, asma, bronchitis & Leaf & Syrup & Cultivated & N.C. \\
\hline Hortelã (Mentha sp., Lamiaceae) & vermifuge & Leaf & Infusion & Cultivated & 87.5 \\
\hline Jaborandi, Pilocarpus microphyllus, Rutaceae) & hair loss & Leaf & $\begin{array}{l}\text { Maceration } \\
\text { and Infusion }\end{array}$ & Cultivated & N.C. \\
\hline Jurubeba (Solanum paniculatum, Solanaceae) & $\begin{array}{l}\text { siuretic and anti- } \\
\text { inflammatory }\end{array}$ & $\begin{array}{l}\text { Roots, } \\
\text { leaves and } \\
\text { fruits }\end{array}$ & $\begin{array}{l}\text { Infusion and } \\
\text { decoction }\end{array}$ & Cultivated & N.C. \\
\hline Laranjeira (Citrus sinensis, Rutaceae) & analgesic and digestive & Leaf & Infusion & Cultivated & 25.0 \\
\hline Levante (Mentha sp., Lamiaceae) & flu & Leaf & Infusion & Cultivated & N.C. \\
\hline Macaé (Leonurus sibiricus, Lamiaceae) & bronchites & Flower & $\begin{array}{l}\text { Infusion and } \\
\text { syrup }\end{array}$ & Cultivated & N.C. \\
\hline Macelinha (Achyrocline satureoides, Asteraceae) & indigestion & Leaf & $\begin{array}{l}\text { Maceration in } \\
\text { water }\end{array}$ & Spontaneous & N.C. \\
\hline Maracujá (Passiflora alata, Passifloraceae) & $\begin{array}{l}\text { diuretic, depurative and } \\
\text { sedative }\end{array}$ & Leaf & Infusion & Spontaneous & 25.0 \\
\hline Margarida (Bellis perennis, Asteraceae) & $\begin{array}{l}\text { stomach problems and } \\
\text { calmant }\end{array}$ & Flower & Infusion & Cultivated & N.C. \\
\hline $\begin{array}{l}\text { Melão-de-são-caetano, (Momordica charantea, } \\
\text { Cucurbitaceae) }\end{array}$ & skin and acne & Leaf & Maceration & Cultivated & N.C. \\
\hline Melissa (Melissa officinalis, Lamiaceae) & digestive and calmant & $\begin{array}{l}\text { Leaf and } \\
\text { stem }\end{array}$ & Infusion & Cultivated & N.C. \\
\hline Mil-folhas/Novalgina (Achillea llefolium,Asteraceae) & colic and ulcer & $\begin{array}{l}\text { Flower and } \\
\text { Leaf }\end{array}$ & Infusion & Cultivated & N.C. \\
\hline
\end{tabular}




\begin{tabular}{|c|c|c|c|c|c|}
\hline Paratudo (Gomphrena arborescens, Amaranthaceae) & stomach and vermifuge & Bark & Infusion & Spontaneous & 37.5 \\
\hline Pata-de-vaca (Bauhinia forficata, Fabaceae) & Diabetes & Leaf & Decoction & Spontaneous & N.C. \\
\hline Pé-de-galinha (Cynodon dactylon, Poaceae) & expectorant & Entire plant & Syrup & Spontaneous & 37.5 \\
\hline Perpétua (Gomphrena globosa, Amaranthaceae) & respiratory disorders & Flower & Infusion & Cultivated & N.C. \\
\hline Picão (Bidens pilosa, Asteraceae) & jaundice & Leaf & Decoction & Spontaneous & 12.5 \\
\hline Poejo (Mentha pulegium, Lamiaceae) & flu & Leaf & Infusion & Cultivated & 37.5 \\
\hline Rebenta-pedra (Phyllanthus niruri, Euphorbiaceae) & kidneys disorders & Leaf & Infusion & Spontaneous & 50.0 \\
\hline Romã (Punica granatum, Punicaceae) & throat infections & $\begin{array}{c}\text { Bark and } \\
\text { seed }\end{array}$ & Decoction & Cultivated & 25.0 \\
\hline Saião (Kalanchoe brasiliensis, Crassulaceae) & flu and inflamations & Leaf & Infusion & Cultivated & 12,5 \\
\hline Transagem (Plantago sp., Plantaginaceae) & throat infections & Entire plant & Decoction & Cultivated & 87.5 \\
\hline Trapoeraba (Commelina nudiflora, Commelinaceae) & allergy & Leaf & Infusion & Cultivated & 37.5 \\
\hline Vick (Mentha arvensis, Lamiaceae) & nasal decongestant & Leaf & Inhalation & Cultivated & 25.0 \\
\hline
\end{tabular}

Source: Data from research

N.C.: Not Calculated

\section{REFERENCES}

Amorozo MCM 1996. A abordagem etnobotânica na pesquisa de plantas medicinais. In: Plantas Medicinais: Arte e Ciência. Um guia de estudo interdisciplinar. São Paulo: UNESP, p. 47-68.

Amorozo MCM 2002. Uso e diversidade de plantas medicinais em Santo Antônio do Leverger, MT, Brasil. Acta Bot Bras 16: 189-203.

Amorozo MCM, Gély AL 1988. Uso de plantas medicinais por caboclos do Baixo Amazonas, Barcarena, PA, Brasil. Boletim do Museu Paraense Emílio Goeldi, Série Botânica 4: 47-131.

Bardin L 1988. Análise de conteúdo. Lisboa: Edições 70, 229p.

Brasil 1998. Ministério da Saúde. Secretaria de Políticas de Saúde. Coordenação Nacional de DST e AIDS. Relatório consolidado do "Encontro Macroregional de Estratégias de Prevenção e Controle das DSTs e AIDS para os povos indigenas da Amazônia Oriental”. Macapá, 40p.

Castellani DC 1999. Plantas medicinais. Viçosa: Agromídia software.

Cotton CM 1996. Ethnobotany: principles and applications. New York: J. Wiley, 996. 320p.

Dias MC 1999. Plantas medicinais utilizadas no Distrito de Juquiratiba - Município de Conchas - SP. Dissertação de Mestrado em Agronomia - área de concentração Horticultura. Faculdade de Ciências Agronômicas da UNESP, Campus de Botucatu, 82p.

Martin GJ 1995. Ethnobotany: a methods manual. London: Chapmam \& Hall.

Martinez PH 1997. Medicinal plants and regional traders in Mexico: physiographic differences and conservational challenge. Econ Bot 51: 107-120.

Müller-Schwarze, NK 2006. Antes and Hoy Día: Plant knowledge and categorization as adaptations to life in Panama in the twenty-first century. Econ Bot 60: 321-334.

Patwardhan B, Vaidya ABD, Chorghade M 2004. Ayurveda and natural products drug discovery. Curr Sci 86: 789-799.
Patwardhan B 2005. Ethnopharmacology and drug discovery. $J$ Ethnopharmacol 100: 50-52.

Rasp RX, It Hisses SM, Kunivoshi YS, It Hisses LB 2000. Etnobiologia of continental communities of the area of ambient protection of Guaraqueçaba, Paraná, Brazil. Etnoecologica 4: 33-55.

Rodrigues AG, Casali VWD 2002. Plantas medicinais, conhecimento popular e etnociência. In: Rodrigues, A. G., Andrade, F. M. C.; Coelho, F. M. G et al. Plantas Medicinais e Aromáticas : etnoecologia e etnofarmacologia. Viçosa: UFV, p. 25-76.

Rodrigues LA, Carvalho DA, Gomes LJ, Botrel RT 2002. Espécies vegetais nativas usadas pela população local em Luminárias, MG. Boletim Agropecuário 52: 1-34.

Rosário da Limeira. Município do Estado de Minas Gerais. Disponível em: http://www.municipionline.com.br/. Acess in 5 March 2007. 